\title{
ALTERNATIF PEMBELAJARAN MENGGUNAKAN CARD GAME PADA ANAK
}

\author{
Khikmah Susanti \\ Universitas Indraprasta PGRI \\ Jagakarsa, Jakarta Selatan-DKI Jakarta \\ soezhan99@gmail.com
}

Naskah masuk: 01-01-21, direvisi: 12-02-2021, diterima: 22-03-21, dipublikasi: 31-04-21

\begin{abstract}
Abstrak: Perkembangan teknologi semakin berkembang pesat. Khususnya dibidang gadget. Tak bisa dipungkiri dari anak kecil hingga dewasa sudah mengenal gadget dengan segala kegunaannya. Meskipun gadget bisa digunakan sebagai media belajar, namun ada dampak negatif yang ditimbulkan. Sehingga orang tua perlu meminimalisir penggunaan gadget kepada anak. Keberadaan Card Game, bisa menjadi media belajar alternatif yang digunakan untuk memberikan pelajaran. Card Game bisa menjadi pilihan yang mengasikkan dan menjadikan waktu kebersamaan menjadi lebih berarti, disaat permainan favorit bisa diakses hanya via ponsel. Bisa dimainkan dimana saja dan kapan saja di jaman yang sudah serba virtual. Card Game tidak hanya berisi tentang permainan, namun ada yang berisi edukasi, seperti Card Game huruf Hijaiyah. Card Game yang berisi edukasi dapat memberikan informasi, dan kesenangan untuk si anak. Dengan bermain sambil belajar diyakini dapat mengasah kemampuan berpikir dan menciptakan kreativitas anak dengan melihat visual yang ada. Selain itu mampu menyusun strategi, mengasah ketelitian, anak menjadi lebih aktif, dapat bersosialisasi dan komunikatif dengan teman, serta menanamkan rasa saling menghormati, dan jujur. Kata kunci: game, anak, edukasi, hijaiyah.
\end{abstract}

\begin{abstract}
The development of technology is growing rapidly. Especially in the field of gadgets. It is undeniable that from small children to adults, they are familiar with gadgets with all their uses. Although gadgets can be used as learning media, there are negative impacts. So that parents need to minimize the use of gadgets to children. The existence of Card Games, can be an alternative learning media used to provide lessons. Card Games can be an exciting choice and make time together more meaningful, when your favorite games can be accessed only via cellphones. Can be played anywhere and anytime in an era that is completely virtual. Card Games are not only about games, but some are educational, such as the Hijaiyah letter Card Game. Card games that contain education can provide information and fun for the child. By playing while learning, it is believed that they can hone their thinking skills and create children's creativity by seeing the existing visuals. Besides being able to develop strategies, hone accuracy, children become more active, can socialize and communicate with friends, and instill mutual respect and honesty.
\end{abstract}

Keywords: games, children, education, hijaiyah

\section{PENDAHULUAN}

Dunia anak, adalah dunia bermain. Terkadang kita sebagai orang dewasa tidak bisa memaksakan anak kecil untuk belajar. Media belajar yang kita kenal saat ini, biasanya berbentuk buku, yang terdapat materi cerita dan gambar-gambar yang menarik. Dan yang sedang kekinian yaitu dengan menggunakan gadget.

Menurut I Gde Widja (1998:60) dalam Sudrajat (2007) menyatakan bahwa media adalah " segala sesuatu yang bisa digunakan sebagai alat bantu dalam rangka mendukung usaha-usaha 
pelaksanaan strategi serta mode mengajar, yang menjurus kepada pencapaian tujuan pengajaran".

$$
\text { Menurut Dientje Borman }
$$

Rumampunk (1998:4) dalam Sudrajat (2007) mengatakan bahwa media yang berasal dari kata jamak dari medium adalah segala sesuatu yang membawa atau menyalurkan informasi antara sumber dan penerima.

Dapat disimpulkan, media pembelajaran adalah alat yang dapat digunakan sebagai media komunikasiyang memiliki tujuan untuk menyalurkan informasi dalam meningkatkan aktivitas proses belajar mengajar.

Buku dan gadget merupakan media komunikasi, namun terkadang buku bisa menimbulkan kebosanan bagi anak. Gadget pun memiliki efek yang tidak baik bagi pertumbuhan si anak. Seperti suka menyendiri, kurang berkomunikasi dan bersosialisasi, tidak perduli dengan sekitar, mudah marah, dan ketergantungan terhadap teknologi.

Untuk mengatasi kebosanan, dan mengalihkan perhatian anak dengan gadget, Card Game bisa menjadi salah satu pilihan. Tak hanya bisa digunakan sebagai permainan, Card Game juga bisa menjadi Media Belajar Alternatif.

$$
\text { Dapat diketahui, sebuah }
$$
pembelajaran selama dilakukan dalam sebuah permainan, dan dalam permainan tersebut terdapat unsur edukasi di dalamnya, dapat membantu memberikan pemahaman

dalam pembentukan karakter, kepribadian maupun pengetahuan si anak dalam belajar.

Yang lebih bermanfaat yaitu dapat mengasah kemampuan berfikir, ketelitian, dan mengingat. Serta merasakan hal yang baru, anak bisa lebih antusias, lebih memacu semangat dan minat mereka dalam belajar. Oleh karena itu penggunaan Card Game dirasa tepat, dapat memberikan suasana baru dalam memberikan pelajaran.

Card Game yang menjadi bahan penelitian, yakni Card Game tentang huruf Hijaiyah, merupakan game edukasi yang bisa di ajarkan kepada anak-anak sejak dini. Karena huruf Hijaiyah merupakan edukasi dasar bagi anak untuk bisa membaca Al-Quran.

\section{METODE}

Pada penelitian ini digunakan metode studi deskriptif kualitatif. Dimana peneliti berusaha menggambarkan suatu gejala sosial, Penelitian ini berusaha untuk menuturkan dan menafsirkan data yang ada, misalnya tentang situasi yang dialami, satu hubungan, kegiatan, pandangan, sikap yang menampak, atau tentang satu proses yang sedang berlangsung.

\section{HASIL DAN PEMBAHASAN}

Kata Game diambil dari bahasa Inggris yang dapat diterjemahkan memiliki arti permainan.

Menurut Clark C. Abt, Game adalah kegiatan yang melibatkan keputusan pemain, berupaya mencapai tujuan dengan "dibatasi oleh konteks tertentu" (misalnya, dibatasi oleh peraturan)

Menurut Greg Costikyan, Game adalah "sebentuk karya seni di mana peserta, yang disebut Pemain, membuat keputusan untuk mengelola sumber daya yang dimilikinya melalui benda di dalam game demi mencapai tujuan". Griffiths (2002: 48) menjelaskan game dapat menyediakan cara yang inovatif dalam pembelajaran, yaitu; 1) Game dapat memberikan unsur interaktivitas yang dapat merangsang pembelajaran; 
2) Game memungkinkan peserta untuk mendapatkan hal yang baru, meningkatkan rasa ingin tahu, dan tantangan yang dapat merangsang dalam pembelajaran; 3) Game dapat membekali anak-anak dengan pengetahuan tentang teknolog; 4) Game data membantu untuk pengembangan skill di bidang IT; dan 5) Game dapat digunakan sebagai simulasi, 6) Game dapat memberikan hiburan seperti masa anak- anak.

Konsep dasar game, Game bermakna "Permainan", teori permainan adalah suatu cara belajar yang digunakan dalam menganalisa sejumlah pemain maupun perorangan yang menunjukkan strategi- strategi rasional.

Teori permainan pertama kali ditemukan oleh sekelompok ahli matematika pada tahun 1994. Teori itu dikemukakan oleh Jhon Von Ann and Oscar Morgenstern, menurutnya permainan terdiri atas sekumpulan peraturan yang membangun situasi bersaing dari 2 atau beberapa orang kelompok dengan memilih strategi yang dibangun untuk memaksimalkan kemenangan sendiri ataupun untuk meminimalkan kemenangan lawan.

Menurut Henry (2010: 111-133) jenis game dapat diklasifikasikan sebagai berikut: 1) Maze Game Jenis game ini menggunakan maze (papan alur) yang dijadikan sebagai latar game. Jenis game ini digunakan oleh game yang paling awal muncul. 2) Board Game Jenis game ini memiliki kesamaan dengan game board tradisional monopoli. Perbedaannya terdapat pada cara memainkannya yang menggunakan komputer. 3) Card Game Jenis game kartu ini memiliki kesamaan dengan permainan tradisional aslinnya. Namun, dalam segi visualisasi lebih bervariasi dan lebih banyak menarik dari versi tradisional. 4) Battle Card Game
Contoh game yang popular yaitu Yugi-Oh dan Duel Master. Game seperti ini sempat marak pada saat film kartun yang menceritakan tentang battle Card Game ditayangkan di stasiun televisi Indonesia. 5) Quiz Game Jenis game ini memiliki bentuk permainan seperti kuis. 6) Puzzle Game Jenis game ini memberi tantangan dengan cara menjatuhkan dan menghilangkan susunan dari atas ke bawah atau dari kiri ke kanan. 7) Shot Them Up Game jenis Shot Them Up memiliki ciri bentuk musuh yang berbentuk pesawat atau bentuk lain yang datang dari sebelah kanan, kiri atau atas layar. 8) Side Scroller Game Jenis ini mengharuskan pemain untuk berjalan, meloncat dan merunduk melewati jalur yang sudah ditentukan, serta menghindari rintangan-rintangan. 9) Fighting Game Jenis game ini merupakan game yang berisi tentang pertarungan. 10) Racing Game Jenis game ini merupakan game tentang balapan. 11) Turn-Based Strategy Game Jenis game ini adalah game yang melakukan gerakan secara bergantian antara pemain satu dengan yang lain. 12) Real-Time Strategy Game Jenis game ini mirip dengan jenis game Turn-Based Strategy, namun dalam jenis game ini pemain tidak harus menunggu giliran. Pemain tercepat yang akan menjadi pemenangnya. 13) SIM Jenis game ini merupakan jenis game berbentuk permainan simulasi.

Di dalam game pemain melakukan kegiatan yang mirip dengan kegiatan sebenarnya, namun permainan berada dalam bentuk simulasi. 14) First Person Shooter Jenis game ini adalah game dimana sudut pandang pemain merupakan pandangan orang pertama. Game ini memiliki banyak baku tembak dan game ini mengutamakan kecepatan gerakan. 15) First Person Shooter 3D 
Vehicle Based Jenis game ini sama dengan jenis game FPS, namun sudut pandang pemain bukan dari orang pertama. Sudut pandang pemain dari mesin atau kendaraan yang digunakan. Kendaraan bisa berupa tank, pesawat, atau kapal. 16) Third Person 3D Games Jenis game ini hampir sama dengan FPS hanya sudut pandang pemain berada pada sudut pandang orang ketiga. 17) RPG (Role Playing Game) Jenis game ini pemainnya memainkan sebuah tokoh atau karakter. Biasanya terdapat alur cerita yang haru dijalankan. 18) Adventure Game Jenis game ini merupakan game petualangan. Di sepanjang permainan pemain akan menemukan alat- alat yang dapat disimpan dan dapat digunakan. Peralatan tersebut juga bisa dapat digunakan sebagai penunjuk jalan. 19) Educational and Edutainment Jenis game ini lebih mengacu pada content dan goal dari game. Game ini bertujuan untuk memancing minat belajar anak sambil bermain. Banyak sekali game yang bergenre Educational and Edutainment, salah satunya adalah Marbel (Mari Belajar). 20) Sports Jenis game ini adalah game yang memiliki tema olahraga.

Game edukasi adalah game yang khusus dirancang untuk mengajarkan user suatu pembelajaran tertentu, pengembangan konsep dan pemahaman dan membimbing mereka dalam melatih kemampuan mereka, serta memotivasi mereka untuk memainkannya.

Salah satunya, Card Game huruf Hijaiyah yang, memang dirancang khusus untuk mengajarkan anak- anak dalam belajar mengenal huruf Hijaiyah, serta membimbing dan melatih kemampuan mereka untuk mengenal huruf Hijaiyah.

Permainan sebagai media pendidikan memiliki banyak peranan. Permainan memiliki sifat luwes. Permainan dapat dipakai untuk berbagai tujuan pendidikan dengan mengubah sedikitsedikit alat, aturan maupun persoalannya (Sadiman, 2011: 79).

Kramer (2000) menjelaskan didalam sebuah game selalu memiliki komponen dan peraturan. Dimana keduanya bisa dikolaborasikan.

Game juga memiliki empat kriteria, yaitu: peraturan permainan, tujuan yang harus dicapai, kesempatan yang ada dalam permainan, dan kompetisi.

Karakteristik game edukasi Menurut Malone dan Lepper (1987: 2) menjelaskan bahwa karakteristik kunci dari game edukasi ada empat karakteristik, yaitu: 1) Tantangan, Tantangan dirancang dengan memiliki tujuan yang jelas, tetap dan relevan untuk pemain. Tantangan dapat digunakan sebagai umpan balik pemain untuk merangsang minat orang yang terlibat. 2) Rasa ingin tahu, Rasa ingin tahu terdapat dua bentuk yang berbeda. Rasa ingin tahu sensorik dan kognitif. Audio dan efek visual, khususnya dalam permainan komputer data meningkatkan rasa ingin tahu sensorik. Sedangkan ketika pemain merasakan efek tertarik, terkejut itu membangkitkan rasa ingin tahu kognitif. 3) Kontrol, Kontrol adalah penentuan nasib sendiri yang dilakukan di dalam game. Kontrol dilakukan untuk menentukan keputusan yang dapat mempengaruhi hasil yang dapat memberikan efek yang baik bagi pemain. Kontrol juga dapat dijadikan sebagai pembelajaran pengalaman. 4) Fantasi, Fantasi meliputi emosi dan proses berpikir. Fantasi tidak hanya menarik untuk kebutuhan emosional pemain, tetapi harus memberikan analogi. Fantasi juga dapat meningkatkan pembelajaran. 
Secara umum manfaat yang didapat dari game edukasi adalah proses pembelajaran menjadi lebih menarik, lebih interaktif, dapat meningkatkan semangat dan minat belajar anak-anak. Game lebih mudah untuk mempertahankan perhatian orang untuk jangka panjang. Proses belajar pun dapat dilakukan dimana dan kapan saja.

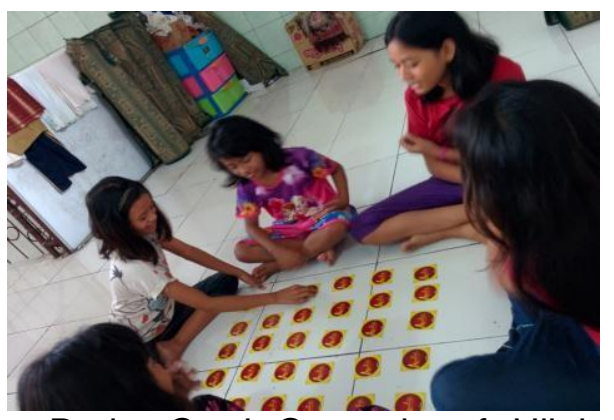

Pada Card Game huruf Hijaiyah, sudah memperlihatkan upaya untuk memenuhi kriteria sebuah game yaitu memiliki peraturan permainan, tujuan yang harus dicapai, kesempatan yang ada dalam permainan, dan kompetisi.

Serta Card Game huruf Hijaiyah apakah sudah memenuhi karakteristik sebagai game edukasi. Ini yang akan menjadi pokok bahasan dalam penelitian.

Card Game huruf Hijaiyah merupakan sebuah permainan sederhana yang menggunakan kartu sebagai alat utamanya, bisa dimainkan bersama beberapa orang untuk menciptakan interaksi antar pemain.

Selain sebagai media belajar alternatif, dengan bermain Card Game dapat mengisi waktu bersama keluarga, yang sekarang ini sudah jarang terlihat. Mereka sudah sibuk dengan gadget masing-masing. Dapat disimpulkan bahwa, Card Game huruf Hijaiyah, sudah memiliki kriteria sebagai Card Game yang memiliki edukasi didalamnya.

Game huruf Hijaiyah memiliki peraturan permainan, yaitu permainan boleh dimainkan oleh empat pemain, dengan memiliki batas usia tiga tahun ke atas.

Tujuan yang harus dicapai, Card Game huruf Hijaiyah memiliki tujuan harus menghabiskan kartu terlebih dahulu dibanding lawannya.

Kesempatan yang ada dalam permainan, di Card Game huruf Hijaiyah kesempatan yang ada mengenal huruf Hijaiyah, angka, dan tanda baca.

Kompetisi, pada Card Game huruf Hijaiyah kompetisi untuk mengalahkan lawan dengan strategi yang baik.
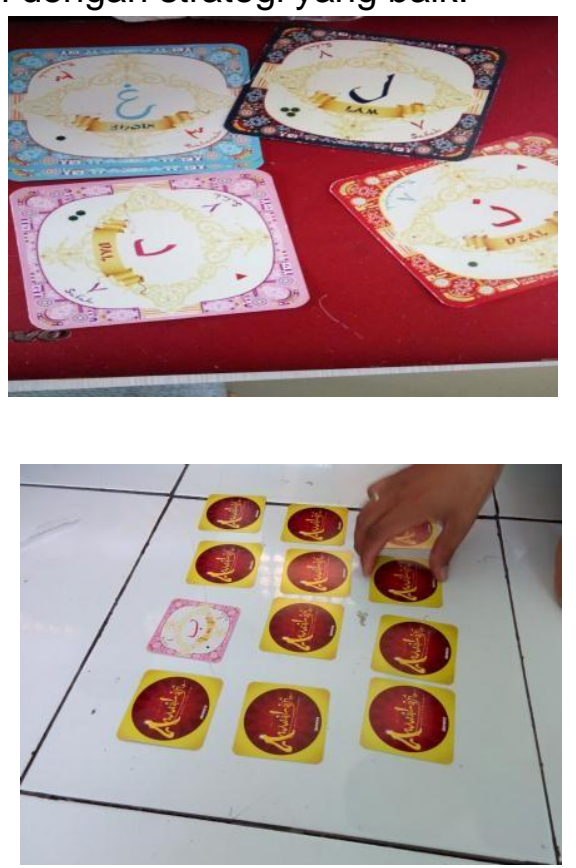

Card Game huruf Hijaiyah juga sudah memiliki karakteristik sebagai game edukasi, yang di dalamya sudah terdapat:

\section{Tantangan}

Pada Card Game, tantangannya menyelesaikan satu mode permainan, dan menjadi pemenang dalam mode permainan tersebut.

\section{Rasa Ingin Tahu}

Pada Card Game huruf Hijaiyah, rasa ingin tahunya masuk ke dalam efek visual yang terdapat pada kartu, yang pada akhirnya meningkatkan rasa ingin tahu sensorik pemainnya. 
Saat bermain pemain merasakan efek tertarik, dan terkejut yang membangkitkan rasa ingin tahu kognitif pemainnya.

\section{Kontrol}

Dalam bermain Card Game huruf Hijaiyah, pemain bisa mengontrol penentuan nasib pemain, menang atau kalah.

\section{Fantasi}

Meliputi emosi dan proses berpikir. Dengan bermain Card Game huruf Hijaiyah, pemain bisa berfantasi melalui visual yang terdapat di kartu huruf Hijaiyah, dengan menggunakan emosi serta proses berfikir untuk mengalahkan lawan pemain.

\section{Penutup}

Bermain tak selamanya tidak baik, ada sisi baik dari bermain yang bisa didapat oleh anak. Bermain game yang berisi edukasi misalnya. Dengan memanfaatkan Card Game yang berisi edukasi.

\section{REFERENSI}

Sudrajat, Ajat (2007). The game of miraclous card: media pembelajaran alternatif berbasis pendidikan karakter dan budaya.

Sumlati, dkk, (2008). Metode Pembelajaran, Bandung: CV Wacana Prima

Susilana, Rudi dan Cepi Riyana. "Media Pembelajaran Hakikat, Pengembangan, Pemanfaatan, dan Penilaian". Bandung: Penerbit CV Wacana Prima.
Card Game bisa dijadikan media belajar alternatif. Dapat memberikan suasana yang baru dalam belajar. Menggunakan Card Game belajar bisa menjadi lebih mengasikkan. Serta dapat mengalihkan perhatian anak terhadap gadget.

Jenis edukasi pada Card Game banyak macamnya. Salah satunya Card Game huruf Hijaiyah. Diyakini dapat memberikan kemudahan kepada anak untuk belajar huruf Hijaiyah dengan konsep visual yang Permainan yang memiliki unsur edukasi diyakini dapat membantu dalam memberikan pemahaman dalam pembentukan karakter, kepribadian, dan pengetahuan si anak dalam belajar. Yang lebih bermanfaat yaitu dapat mengasah kemampuan berfikir, ketelitian, dan mengingat. Serta merasakan hal yang baru yang lebih memacu minat mereka untuk belajar.

http://guraru.org/guru-berbagi/pemanfaatanboard- game-dan-card-game-dalampembelajaran/

http://windycitra.blogspot.co.id/2016/02/boar d- $\quad$ game-dan-card-game-bisamenjadi.html

http://mohammadmahareza.blogspot.com/ 2014/04/pengertian-teknologigame.html

www.googleweblight.com : Board Game dan Card Game bisa menjadi media belajar alternatif. 